\title{
The Use of Online Corrective Feedback in Academic Writing by L1 Malay Learners
}

\author{
Soo Kum Yoke ${ }^{1}$, Cecilia Bai Rajendran ${ }^{1}$, Noridah Sain $^{1}$, Puteri Nur Hidayah Kamaludin ${ }^{1}$, Sofwah Md Nawi ${ }^{1} \&$ \\ Suhaili Mohd Yusof ${ }^{1}$ \\ ${ }^{1}$ Academy of Language Studies, Universiti Teknologi MARA Cawangan Johor, Malaysia \\ Correspondence: Soo Kum Yoke, Academy of Language Studies, Universiti Teknologi MARA Cawangan Johor, \\ KM 12, Jalan Muar, 85000 Segamat, Johor, Malaysia. Tel: 60-7935-2166. E-mail: sooku607@johor.uitm.edu.my
}

Received: August 12, 2013 Accepted: September 13, 2013 Online Published: November 5, 2013

doi:10.5539/elt.v6n12p175 URL: http://dx.doi.org/10.5539/elt.v6n12p175

The research is financed by the Excellence Fund, Universiti Teknologi MARA Cawangan Johor.

\begin{abstract}
Conventional corrective feedback has been widely practiced but has been said to be tedious, stressful and time consuming. As such, the focus of this study is to investigate the use of an alternative method to giving corrective feedback namely, an online corrective feedback through e-mail. In order to examine if this innovative form of corrective feedback can be applied to the teaching and learning of academic writing, an experimental design was used with a control group and an experimental group of L1 Malay learners who were pursuing an academic writing course at the tertiary level. Interviews were also conducted on selected individuals to determine whether the use of online corrective feedback was practical in assisting learners improve their writing from the first draft to the final product. The statistical analysis applied to this research indicated that online corrective feedback may be an effective way to improve writing skills of learners and save time. Thus, the results showed that online corrective feedback should be potentially useful when integrated into the teaching and learning of academic writing.
\end{abstract}

Keywords: conventional corrective feedback, online corrective feedback, writing process

\section{Introduction}

\subsection{Background of the Study}

The teaching of writing in the second language classroom is considered a painstaking activity and the debate of whether to provide ESL learners with corrective feedback has been of great interest to researchers and language instructors (Ferris, 2000, 2002, 2004; Truscott, 1996, 1999). Normally, writing is used as a yardstick to gauge a learner's grasp of the language. Thus, it is important for ESL instructors to find ways to improve their students' writing skills more effectively in order to increase their performances. With the advent of computers in the teaching and learning environment, ESL instructors have started integrating computer-based programmes like word processors in the writing classroom.

ESL instructors spend hours in identifying and correcting their students' errors but it has been found that students do not bother to read the comments given by their instructors much less to correct them. This is because more often than not, students are put off by the red markings and illegibility of the instructor's handwriting. Thus, this issue needs to be addressed to find ways to solve this problem. The objective of this study is to examine whether online corrective feedback as opposed to conventional corrective feedback can improve tertiary learners' performance in academic writing and if so, to what extent.

ESL learners have been found to have responded positively to the online mode of corrective feedback as opposed to conventional corrective feedback through pen and paper. This is not surprising as students these days are fascinated with gadgets like computers, smart phones and tablets which have online connections. This enables them to access their written assignment anytime, any place and provides them the flexibility of responding to the comments given by counter responding if they are unsure or have queries. According to $\mathrm{Li}$ and $\mathrm{Li}$ (2012), students who favoured corrective feedback had high motivation of learning and their writing have been found to have improved without the use of simplified lexis and syntax. Van Beuningen, De Jong and Kuiken (2012) assert 
that both direct and indirect corrective feedbacks provide long-term linguistic accuracy in academic writing. Research on the effectiveness of corrective feedback has been generally positive (Lyster \& Ranta, 2013). However, whether corrective feedback is effective in improving writing skills is still a controversial issue. Ferris (2004, as cited in Guenette, 2007) remarked that it cannot be ascertained that error rectification works. Guenette (2007) states that ESL instructors have been considering whether they should correct the grammar in their students' essays since there are contradictions to the effectiveness of this practice.

\subsection{Conventional Corrective Feedback}

Corrective feedback comes in various forms such as content comments, error correction, error correction and content comments and, error identification without corrections. It can be divided into direct or indirect feedback. Direct feedback is also known as explicit feedback. The instructor giving direct feedback usually identifies the errors and corrects them on the learners' written essay. Indirect feedback is when the instructor identifies the error but does not provide the correct form. Nonetheless, he or she may provide codes as clues of the errors committed such as $v t$ to represent verb tense error. In most cases however, the instructor would underline, circle or place an error tally in the margin to indicate the mistake the students have committed. Ferris et al. (2000) investigated the effects of direct and indirect error correction and it was found that more students revised their essays (88\%) under the direct error feedback compared to the indirect error feedback (77\%). However, the study showed that at the end of the semester, there was significant reduction of errors made by students who received the indirect error feedback. In another study, Ferris and Roberts (2001) investigated the use of corrective feedbacks in the form of errors marked with codes, errors underlined but not marked and no error feedback. Overall, the results favoured the use of corrective feedback. The treatment of corrective feedbacks in the form of errors marked with codes, and errors underlined but not marked, outperformed the treatment of no error feedback. Hartshorn and Evans (2012) in their study of corrective feedback also discovered that L2 students who received corrective feedback improved significantly in their writing.

\subsection{Online Corrective Feedback}

Li (2000) investigated the use of online task-based activities in a process oriented writing class. The results showed that students were able to produce more syntactically and lexically complex essays. Students were found to be receptive to receiving feedback via e-mail compared to the conventional corrective feedback method using pen and paper. In another study, Razagifard and Razzaghifard (2011) found that students who were given computer mediated corrective feedback outperformed those without feedbacks. However, in a study on the use of corrective feedback in a computer assisted practice exercise, it was found that corrective feedback was ineffective (Adams, Ruifang \& Hope, 2012). Truscott (2007) also found that corrective feedback was ineffective and produced negative results because students feel pressured and demotivated when their essays are filled with errors. Rami (2012) found that Saudi students have poor perception of corrective feedback based on cultural factors. In a study on the motivational levels of learning with or without the use of computers, it was found that there was no significant difference as to whether the use of computers increased motivational levels of learning as students were found in general, to fear any form of corrective feedback (Ali, 2011). This is in contrast to the study conducted by Hosseini (2012) which indicated that using computers and the internet had significant motivational effect on the students. Nezami (2012) also found that online corrective feedback, mainly recasts and metablinguistic feedbacks, was beneficial to learners.

\subsection{Perceptions about Corrective Feedback}

It is important to consider how students and language instructors perceive corrective feedback as there are differing views on the matter. According to Lee (2005), secondary school students in Hong Kong seem to prefer direct corrective feedback instead of indirect corrective feedback as they deemed their language instructors more competent in the language. Liang (2008) found that students preferred identification of errors by underlining and coded feedbacks to enable them to improve their writing. There are ESL instructors who prefer to provide thorough corrective feedback of a learners' written work by means of identifying each and every mistake (Ellis et al., 2008). However, this may not be an effective way of helping students improve their written work. Others have worked on one linguistic feature at a time to assist students in reducing errors.A study conducted by Scheeler, McKinnon and Stout (2012) found that using online corrective feedback had positive effect on 5 pre service teachers. However, ESL instructors were also encouraged to find out their students' preference for corrective feedback before the writing lesson. 


\section{Method}

\subsection{Sampling Size}

The participants for this research were selected using a convenient sampling method from two academic writing classes. The 44 students selected from these two classes agreed to participate in this experiment. The first group of 22 students was exposed to the conventional corrective feedback for their writing drafts while the second group of another 22 students was exposed to the online corrective feedback for their writing drafts. The participants were all L1 Malay students and consisted of both male and female students who have passed the Intermediate English course in the previous semester with at least a $\mathrm{C}$ grade. They were around the age of 20 to 22 years old.

\subsection{Research Instrument}

There were two research instruments used for this research. The first set of instrument was a writing assignment. The participants were required to complete their writing assignments of 700 words within the period of 14 weeks. They were required to hand in an outline on Week 6, and the first draft on Week 8. The final draft was to be handed in on Week 14.

The second instrument was an interview. Selected students were asked about their preference of the feedbacks given for their drafts.

\subsection{Research Procedure}

This study uses an experimental method to investigate the feasibility of using online corrective feedback as opposed to conventional corrective feedback in the ESL academic writing classroom. There were two groups of participants for this experiment. The first group, the control group, was given conventional corrective feedback on their writing drafts while the second group, the experimental group, was given online corrective feedback on their writing drafts.

In the control group, the students had to hand in their type written work in hard copy to be corrected and graded. The instructor would then write comments and correct the work using a red pen after which, the drafts would be returned to the class to be rectified before handing in the final draft. In the experimental group, the students had to hand in their type written work in soft copy via email. The instructor would then provide corrective feedback using the word processor (MS-Word) application features such as highlighting, reviewing, commenting, etc. before returning the written work via email. The grading is done for both the first and final drafts. The first draft is graded $10 \%$ and the final draft is graded $15 \%$ in accord with the course specification. Interviews were also conducted informally with students to identify their preferences and perceptions on using the corrective feedback methods.

Two sets of data are collected from the experiment. In the first set, data collected from both the control and experimental groups are analysed based on the types of errors commited which are mainly errors on sentence structure, grammar and vocabulary. In the second set, data collected are tabulated based on the scores of the first and final drafts. They are then converted to percentages before running a t-test. This is mainly done to see the significance of using the online corrective feedback in comparison to the conventional corrective feedback. This should explain if using online corrective feedback is better than conventional corrective feedback and if so, to what extent.

\section{Results}

The result of this study shows that using online corrective feedback is indeed viable as the students who were given online corrective feedbacks perfomed better compared to those who were given conventional corrective feedbacks. This supported previous studies that stated students responded better via email (Li, 2011) and outperformed those who did not receive computer-mediated feedback (Rassaghifard, 2012). From the first draft to the final draft it was found that students who received online corrective feedback had a decreased number of errors committed for sentence structure (47.4\%), grammar (70.6\%) and vocabulary (45.4\%). There was also a decrease in the number of errors committed for the conventional corrective feedback for sentence structure $(23.2 \%)$ and vocabulary (17.6\%). Grammatical errors showed no improvement. The results indicated that there was more improvement received from the online corrective feedback compared to the conventional corrective feedback. 
Table 1. Comparison of errors for online corrective feedback and conventional corrective feedback

\begin{tabular}{lllllll}
\hline & \multicolumn{3}{l}{ Sentence Structure } & Grammar & \multicolumn{3}{l}{ Vocabulary } \\
& CCF & OCF & CCF & OCF & CCF & OCF \\
& $(\%)$ & $(\%)$ & $(\%)$ & $(\%)$ & $(\%)$ & $(\%)$ \\
Draft 1 & 61.6 & 73.7 & 50 & 85.3 & 58.8 & 72.7 \\
Draft 2 & 38.4 & 26.3 & 50 & 14.7 & 41.2 & 27.3 \\
\hline
\end{tabular}

$\mathrm{CCF}=$ Conventional Corrective Feedback; OCF $=$ Online Corrective Feedback

Table 1 shows the comparison of errors committed by the students in the control and experimental groups. The control group was given conventional corrective feedback while the experimental group was given online corrective feedback. The results show that both the groups showed improvement after corrective feedbacks were given. The experimental group with online corrective feedback however, showed better performance with a decreased number of errors between Draft 1 and Draft 2 compared to the performance of the control group.

A paired sample t-test was run and the results are shown in table 2 below.

Table 2. Paired samples t-test result

\begin{tabular}{ll}
\hline Pairs & Sig (2-tailed) \\
\hline Pair 1 (Draft 1) & .830 \\
Pair 2 (Draft 2) & .000 \\
\hline
\end{tabular}

Table 2 shows the significant value of pair 1 and pair 2. For pair 1 (Draft 1 between the control and experimental groups), the $\mathrm{p}$ value is .830 ( $\mathrm{p}>.05)$. This indicates that there is no significant difference in the performance of both the control and experimental groups. It also shows that both groups are of similar ability and show similar performance in the writing of the first draft (Draft 1). For pair 2 (Draft 2 between the control and experimental groups), the $\mathrm{p}$ value is $.000(\mathrm{p}<.05)$. This means that there is a significant difference after the different treatments were applied to the groups. The experimental group who were treated with online corrective feedback outperformed the control group with the conventional corrective feedback.

The informal interviews supported the views that the students were more interested in receiving online corrective feedbacks via e-mail. In figure 1, it has been found that $78.57 \%$ of the students preferred receiving the online corrective feedback.

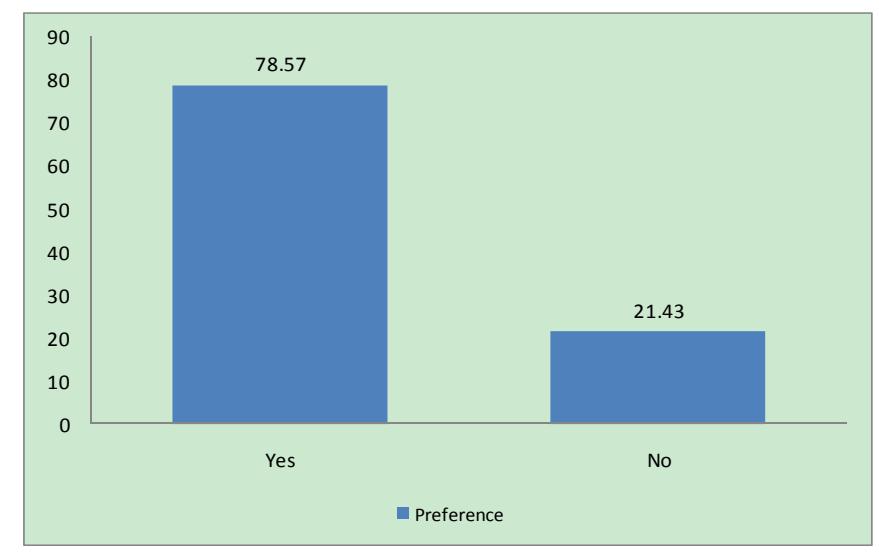

Figure 1. Preference for online corrective feedback

To facilitate the research, the students were also asked the reasons why they preferred receiving online corrective feedbacks. $63.6 \%$ of the students stated that they found it easier to submit and get feedback using this method. $45.5 \%$ stated that the online corrective feedback was easier to use and it was time saving. Another $36.4 \%$ stated that the reason why they preferred online corrective feedback was because they did not have to rewrite the whole essay for corrections. $18.2 \%$ of the students agreed that the assignments will not get lost but be saved in their 
emails. Only a small percentage (9.1\%) agreed that this approach was cheaper than using the conventional corrective feedback method. The results of the interview can be seen in Table 3 below.

Table 3. Reasons for preference of online writing

\begin{tabular}{ll}
\hline Reasons & Percentage (\%) \\
\hline Easier to submit and get feedback & 63.6 \\
Easier to use & 45.5 \\
Time saving & 45.5 \\
Cheaper & 9.1 \\
Don't have to rewrite the whole essay for corrections & 36.4 \\
Assignments will not get lost but be saved in the email & 18.2 \\
\hline
\end{tabular}

\section{Discussion}

This study has helped in determining whether the use of online corrective feedback is better than the use of conventional corrective feedback in the academic writing classroom. The experimental study seem to indicate that students prefer receiving feedbacks via email (online) rather than written comments (through pen and paper) by their instructors. Firstly, the findings show that the students who received online corrective feedback outperformed those who did not. The findings also show that they improved in their sentence structure, grammar and vocabulary significantly better than those who received conventional corrective feedback.

The students were also found to be more motivated to do the corrections to the errors committed as the use of electronic devices appealed to them. This supports previous studies (Hosseini, 2012; Li, 2000; Razagigard \& Razzaghifard, 2011) which showed that using computers had significant motivational effect on students. Most of the students agreed that they preferred receiving online corrective feedback because of the user-friendly facilities available in computers. Fore example, they can access their assignments in their emails and can be assured that their assignments will not be lost. They also need not rewrite the whole essay when doing corrections. Instead, they only need to rectify the portions that needed amendments. This indicates the feasibility and potential of using online corrective feedback for both instructors and students alike.

While this is the case, the conclusion is only preliminary as the sample size for this study is rather small with the comparison of the two groups. It is therefore recommended that in future studies a larger sample size is applied to the study perhaps in different levels of education. The study also found that utilizing the email online had positive effect on the students. In future studies, it is recommended that online social networking sites like facebook or blogs be tested for use in the academic writing classroom.

\section{References}

Adams, Ruifang, \& Hope. (2012). The Effects of Computer-Assisted Feedback Strategies in Technology Education: A Comparison of Learning Outcomes. Journal of Educational Technology Systems.

Ali Karakas. (2011). Motivational Attitudes of ELT Students Towards Using Computers For Writing And Communication. Teaching English with Technology, 11(3), 37-53.

Bitchener, J., East, M., \& Cartner, H. (2010). The effectiveness of providing second language (L2) writers with on-line written corrective feedback.

Ellis, R., Sheen, Y., Murakami, M., \& Takashima, H. (2008). The effects of focused and unfocused written corrective feedback in English as a foreign language context. System, 36, 353-371. http://dx.doi.org/10.1016/j.system.2008.02.001

Ferris, D. (2004). The "grammar correction" debate in L2 writing: Where are we, and where do we go from here? (And what do we do in the meantime?). Journal of Second Language Writing, 13, 49-62. http://dx.doi.org/10.1016/j.jslw.2004.04.005

Ferris, D. R. (2002). Treatment of error in second language student writing. Ann Arbor: University Michigan Press.

Ferris, D. R., Hsiang Liu, Sinha, A., \& Senna, M. (2012). Written corrective feedback for individual L2 writers. Journal of Second Language Writing. http://dx.doi.org/10.1016/j.jslw.2012.09.009

Ferris, D., \& Roberts, B. (2001). Error feedback in L2 writing classes. How explicit does it need to be? Journal 
of Second Language Writing, 10, 161-184.

Guenette, D. (2007). Is feedback pedagogically correct? Research design issues in studies of feedback on writing. Journal of Second Language Writing, 16, 40-53.

Hartshorn, J., \& Evans, N. (2012). The Differential Effects of Comprehensive Corrective Feedback on L2 Writing Accuracy. Journal of Linguistics and Language Teaching.

Hosseini, S. B. (2012). Asynchronous Computer-Mediated Corrective Feedback and the Correct Use of Prepositions: Is it really effective? Turkish Online Journal of Distance Education.

Lee, I. (2005). Error correction in the L2 writing classroom: What do students think? TESOL Canada Journal, 22(2), 1-16.

Liang, Y. (2008). The effects of error feedback in second language writing. Second Language Acquisition and Teaching, 15, 65-79.

Li, S., \& Li, P. (2012). Individual differences in written corrective feedback: A multi-case study. English Language Teaching, 5(11), 38-44. http://dx.doi.org/10.5539/elt.v5n11p38

Li, Y. (2000). Linguistic characteristics of ESL writing in task-based e-mail activities. System, 28(2), 229-245. http://dx.doi.org/10.1016/S0346-251X(00)00009-9

Lyster, R., \& Ranta, L. (2013). Counterpoint piece: The case for variety in corrective feedback research. Studies in Second Language Acquisition, 167-184. http://dx.doi.org/10.1017/S027226311200071X

Kolade, T. A. (2012). The Influence of Process Approach on English as Second Language Students' Performances in Essay Writing. English Language Teaching, 5(3), 16-29. http://dx.doi.org/10.5539/elt.v5n3p16

Nezami, S. H. (2012). A study of errors, corrective feedback and noticing in synchronous computer mediated communication. (Master's thesis). Retrieved from http://urn.kb.se/resolve?urn=urn:nbn:se:liu:diva-88411

Rami F. Mustafa. (2012). Feedback on the Feedback: Sociocultural Interpretation of Saudi ESL Learners' Opinions about Writing Feedback. English Language Teaching, 5(3), 3-15. http://dx.doi.org/10.5539/elt.v5n3p3

Razagifard, P., \& Razzaghifard, V. (2011). Corrective Feedback in a Computer-Mediated Communicative Context and the Development of Second Language Grammar. Teaching English with Technology, 11(2), $1-17$.

Scheeler, M. C., McKinnon, K., \& Stout, J. (2012). Effects of Immediate Feedback Delivered via Webcam and Bug-in-ear Technology on Preservice Teacher Performance. http://dx.doi.org/10.1177/0888406411401919

Truscott, J. (2007). The effect of error correction on learners' ability to write accurately. Journal of Second Language Writing, 16, 255-272. http://dx.doi.org/10.1016/j.jslw.2007.06.003

Truscott, J. (2004). Evidence and conjecture on the effects of correction: A response to Chandler. Journal of Second Language Writing, 13, 337-343. http://dx.doi.org/10.1016/j.jslw.2004.05.002

Truscott, J. (1997). "The case for grammar correction in L2 writing classes": A response to Ferris. Journal of Second Language Writing, 8, 111-122. http://dx.doi.org/10.1016/S1060-3743(99)80124-6

Truscott, J. (1996). The case against grammar correction in L2 writing classes. Language Learning, 46, 327-369. http://dx.doi.org/10.1111/j.1467-1770.1996.tb01238.x

Van Beuningen, C., De Jong, N. H., \& Kuiken, F. (2012). Evidence on the effectiveness of comprehensive error correction in second language writing. Language Learning, 62(1), 1-41. http://dx.doi.org/10.1111/j.1467-9922.2011.00674.x

\section{Copyrights}

Copyright for this article is retained by the author(s), with first publication rights granted to the journal.

This is an open-access article distributed under the terms and conditions of the Creative Commons Attribution license (http://creativecommons.org/licenses/by/3.0/). 